\title{
Biodiversity of planktonic hydrozoans from a subtropical estuary: evidence of assemblage structure change
}

\author{
LORENA SILVA NASCIMENTO ${ }^{1}$, MIODELI NOGUEIRA JÚNIOR ${ }^{2}$, EMANUELLE MACÊDO VIANA ${ }^{2}$ \\ AND JOSÉ GUILHERME F. BERSANO ${ }^{1}$ \\ ${ }^{1}$ Zooplankton Laboratory, Centro de Estudos do Mar, Universidade Federal do Paraná, Avenida Beira-mar, CP 61, ZIP code 83255- \\ 976 Pontal do Sul, Pontal do Paraná, Paraná, Brazil, ${ }^{2}$ Departamento de Sistemática e Ecologia, Universidade Federal da Paraíba, \\ Cidade Universitária, ZIP code 58051-900 João Pessoa, Brazil
}

\begin{abstract}
The present study provides a comprehensive survey of the planktonic hydrozoan fauna from the Paranaguá Estuarine System (PES; southern Brazil, $25^{\circ} \mathrm{S} 48^{\circ} \mathrm{W}$ ), a subtropical estuary considered a Natural World Heritage site by UNESCO. Extensive collections were performed throughout the estuary in five sampling campaigns during the summer and winter periods of 2012 and 2013 and summer of 2014, totalling 185 samples. About 49,0oo organisms were analysed which together with the few previous records resulted in a total of 36 hydromedusae and three siphonophore species. We highlight the presence of Cnidostoma fallax in high abundance ( $>19$,ooo individuals captured; $\sim 40 \%$ of all planktonic hydrozoans). The high abundance of this species throughout three consecutive summers suggests a change in the local assemblage structure, since previous reports in the 1980s, 1990s and 20oos had shown Liriope tetraphylla recurrently as the dominant species which now ranks fourth. It is difficult to ascertain the causes of such changes due to the paucity of previous studies on Brazilian estuaries, but one possibility is that $\mathrm{C}$. fallax has been recently introduced. In any case, the high dominance of this hydromedusa was not expected and this scenario would potentially cause changes in the local food web since C. fallax and L. tetraphylla are quite different morphologically and ecologically and thus probably play different trophic roles. Future studies are necessary to check the long-term permanency of $\mathrm{C}$. fallax and to assess its biology and ecology and the impact of this assemblage change on the ecosystem.
\end{abstract}

Keywords: Cnidostoma fallax, NIS jellyfish, introduced species, ecosystem change, hydromedusae, siphonophores, marine conservation Submitted 1 August 2017; accepted 7 June 2018; first published online 8 August 2018

\section{INTRDDUCTION}

The knowledge of species composition of a given ecosystem is one the most basic aspects of biodiversity research, being essential for natural resource management and to assure quality in biological and ecosystem sciences (Costello et al., 2013). Many areas lack comprehensive systematic inventories and this is particularly true for marine ecosystems that in general are much less studied than terrestrial ones (Bouchet, 2006). Additionally, biodiversity is often considered to be under major threat mostly due to anthropogenic pressure (Carlton, 1996, 2000; Dulvy et al., 2003; Costello et al., 2013). However, the lack of historical data hampers an accurate detection of assemblage changes such as invasions and/or local extinctions. This may be particularly true for planktonic hydrozoans which are typically small, delicate and historically under-studied worldwide (e.g. Bouillon et al., 2004), and particularly in Brazil (Haddad \& Marques, 2009), underscoring

Corresponding author:

L.S. Nascimento

http://orcid.org/oooo-0003-1622-8627

http://orcid.org/oooo-0001-5409-8312

Email: nascimento.s.lorena@gmail.com the need for comprehensive efforts to develop taxonomic inventories such as the present study.

Estuarine ecosystems are particularly vulnerable since they harbour an abundant and diversified biota (Dolan \& Gallegos, 2001; Bouchereau et al., 2008; Paiva et al., 2013; Seguro et al., 2015) and are often pressured by human occupation and activities nearby with associated impacts (e.g. Cremer et al., 2006). Among the many human pressures, such as pollution and habitat fragmentation, growing attention has been given to nonindigenous species. There is an increased awareness that invasive species can change abundance of indigenous species and play an important role in species extinctions (Gallardo et al., 2016), being considered a great threat to marine ecosystems.

The Paranaguá Estuarine System (PES) is one of the largest estuarine systems of South America, with $\sim 550 \mathrm{~km}^{2}$ of total water body (Noernberg et al., 2006). PES harbours a large biodiversity and has been adopted a Natural World Heritage site by UNESCO (2016). Besides its ecological importance, PES is also important for harbouring two ports; the port of Paranaguá, the main South American grain-shipping port (Marone et al., 2000), and the port of Antonina. No comprehensive surveys on planktonic hydrozoans from PES have been performed, despite their ecological importance (e.g. Matsakis \& Conover, 1991; Mills, 1995) and high diversity. The few existing studies recorded 18 species, three of them 
regarded as probably exotic (Montú \& Cordeiro, 1988; Nogueira Júnior \& Oliveira, 2006; Bardi, 2011; Haddad et al., 2014). In the present study we aim to provide a comprehensive overview of planktonic hydrozoan diversity from PES, along with evidence of regional assemblage change compared with the past decades.

\section{MATERIALS AND METHODS}

Planktonic hydrozoans were collected in five seasonal sampling campaigns: summer (13-16 March) and winter (23 and 24 August) 2012, summer (21 and 22 February) and winter (18 and 19 June) 2013, and summer (28 and 29 March) 2014. For each campaign, 37 stations were sampled (Figure 1), totalling 185 samples. PES can be divided in five sectors (Paranaguá, Antonina, Laranjeiras and Pinheiros Bays and a mixing zone) based on Noernberg et al. (2006). In the present study, with exception of Antonina Bay, all the sectors, along with two main tidal channels were sampled.

Oblique tows (speed $=2$ knots for $2 \mathrm{~min}$ ) from near the bottom to the surface were made, with a WP-2 plankton net ( $2 \mathrm{~m}$ long, $0.5 \mathrm{~m}$ mouth diameter, $200 \mu \mathrm{m}$ mesh) equipped with calibrated mechanical flowmeters Hydrobios in 2012 samplings campaigns and General Oceanics in 2013. Samples $(\mathrm{N}=185)$ were preserved with a $4 \%$ formaldehyde (borax-buffered) solution for later analysis in the laboratory. In addition, surface temperature and salinity were measured at each station with a mercury thermometer and calibrated portable refractometer Atago, respectively.
Whole samples were analysed in the laboratory under a stereomicroscope and all the planktonic hydrozoans were sorted and identified (mostly following Bouillon, 1999 and Pugh, 1999). A list with all species found, along with the literature records was compiled and is presented (Table 1). Classification follows Schuchert (2016). The number of analysed individuals (colonies for siphonophores) and the frequency of capture of a given species are also tabulated.

Species accumulation curves and diversity estimators such as Chao 1 and 2, and Jackknife 1 and 2 were constructed for all sampling campaigns, using the program Primer v6 (Clarke \& Gorley, 2006).

\section{RESULTS AND DISCUSSION}

In the present study we have sampled and analysed about 49,000 hydrozoan specimens belonging to 34 species, these being three siphonophores and 31 hydromedusae, apart from actinula larvae (Table 1). Some representative examples are shown in Figures 2-14. In many cases the quality of the material was not good, as is usual with these delicate organisms and therefore for detailed morphological analyses, examination of live organisms is recommended whenever possible. In the present collection, the diagnostic characters could be seen in most cases, allowing a reliable identification aided by the strong taxonomic background of some of the authors (LSN and MNJ). In fact, damaged unidentifiable organisms did not represent a significant proportion of the collection and accounted for less than $1 \%$ of the total organisms

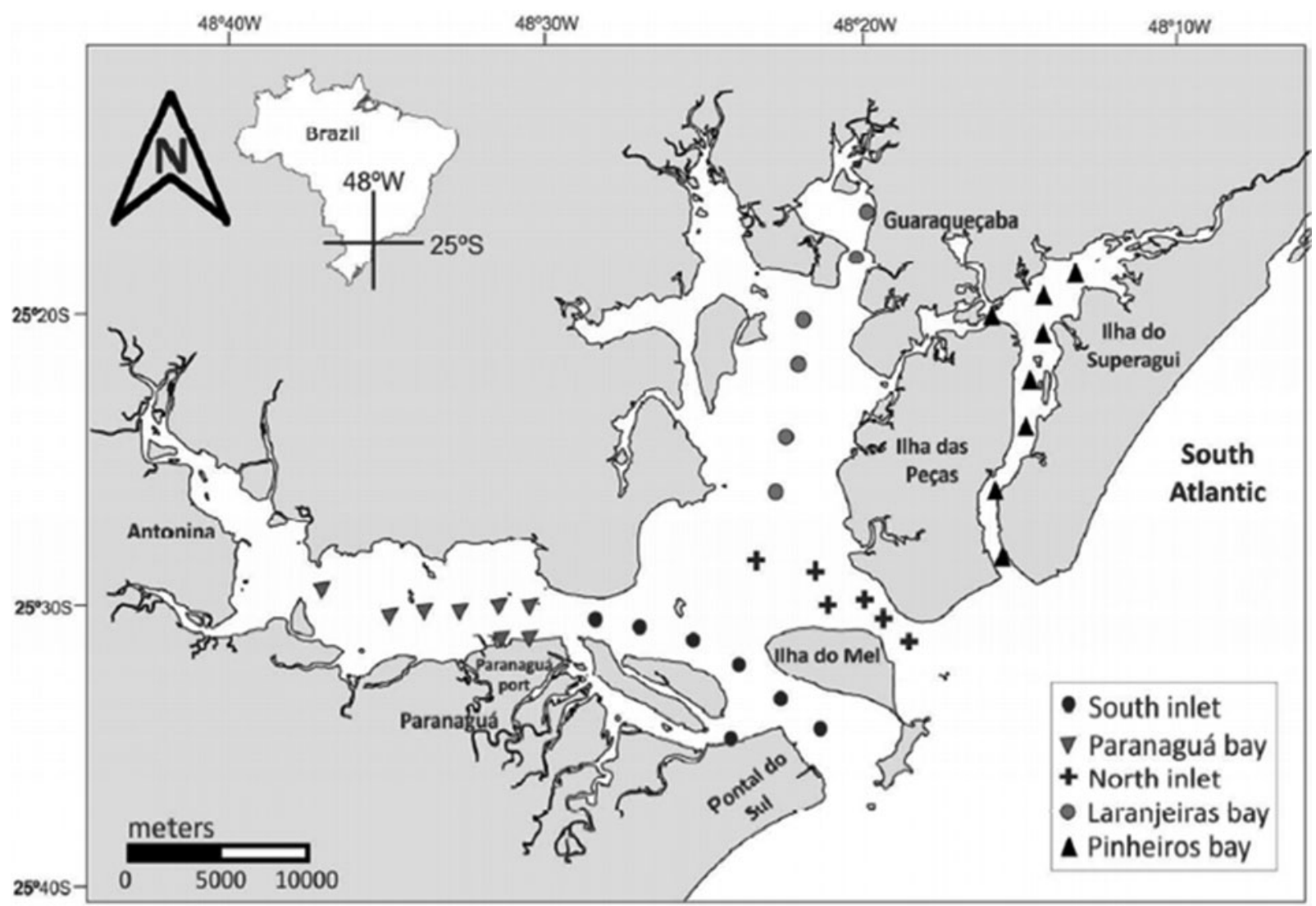

Fig. 1. Map of Paranaguá Estuarine System, southern Brazil, showing the 37 stations sampled on March and August 2012, February and June 2013, and March 2014, in each sector: inlets, mixing zone, Paranaguá, Laranjeiras and Pinheiros Bays. Map was made in the QGis 2.18 software. 
Table 1. Taxonomic classification, frequency of capture (FC) and number of individuals (colonies for siphonophores) of planktonic hydrozoans recorded in the present study, in Paranaguá Estuarine System, southern Brazil, from 185 plankton hauls.

\begin{tabular}{|c|c|c|c|c|c|c|c|c|c|c|c|}
\hline \multirow[t]{2}{*}{ Species } & \multirow[b]{2}{*}{$\begin{array}{l}\text { FC } \\
(\%)\end{array}$} & \multicolumn{6}{|c|}{ Number of individuals } & \multirow[b]{2}{*}{$\mathrm{S}$} & \multirow[b]{2}{*}{$\mathrm{T}\left({ }^{\circ} \mathrm{C}\right)$} & \multirow[b]{2}{*}{ PES sector } & \multirow[b]{2}{*}{$\begin{array}{r}\text { Data } \\
\text { Source }\end{array}$} \\
\hline & & Total & $\begin{array}{l}\text { Summer } \\
2012\end{array}$ & $\begin{array}{l}\text { Winter } \\
2012\end{array}$ & $\begin{array}{l}\text { Summer } \\
2013\end{array}$ & $\begin{array}{l}\text { Winter } \\
2013\end{array}$ & $\begin{array}{c}\text { Summer } \\
2014\end{array}$ & & & & \\
\hline Actinula larvae & 23.2 & 945 & 667 & 121 & 145 & o & 12 & $33-23$ & $30-19$ & In/MZ/Pguá/Lar/Pin & 1 \\
\hline \multicolumn{12}{|l|}{ Subclass Hydroidolina Order Anthoathecata } \\
\hline \multirow{2}{*}{\multicolumn{12}{|c|}{$\begin{array}{l}\text { Suborder Filifera } \\
\text { Family Boungainvillidae }\end{array}$}} \\
\hline & & & & & & & & & & & \\
\hline Bougainvillia muscus (Allman, 1863) ${ }^{\mathrm{a}}$ & 19.4 & 92 & 34 & 29 & 4 & 7 & 18 & $34-16$ & $29-20$ & Pguá/Pin & 1,3 \\
\hline Bougainvillia frondosa Mayer, 1900 & 1.6 & 6 & o & 6 & o & 0 & 0 & $34-30$ & $21-20$ & Pin & 1 \\
\hline Bougainvillia carolinensis (McCrady, 1859) & 2.1 & 8 & 8 & o & o & o & o & $29-10$ & $30-20$ & Pguá/Lar & 1,3 \\
\hline \multicolumn{12}{|l|}{ Family Hydractiniidae } \\
\hline Cnidostoma fallax Vanhöffen, 1911 & 52.9 & 19455 & 16260 & 112 & 2910 & 1 & 172 & $34-17$ & $31-20$ & In/MZ/Pguá/Lar/Pin & 1 \\
\hline Podocoryna loyola Haddad et al., 2014a & 18.4 & 355 & 1 & 6 & 3 & 16 & 329 & $34-16$ & $29-19$ & In/Pguá/Lar & 1,6 \\
\hline \multicolumn{12}{|l|}{ Family Rathkeidae } \\
\hline Lizzia blondina Forbes, 1848 & 4.8 & 20 & 5 & 14 & 1 & 0 & o & $34-15$ & $30-21$ & Pguá & 1,3 \\
\hline \multicolumn{12}{|l|}{ Family Oceaniidae } \\
\hline Turritopsis nutricula McCrady, 1857 & 5.4 & 12 & 3 & 2 & 5 & 2 & o & $34-14$ & $30-20$ & MZ/Pguá/Lar/Pin & 1 \\
\hline \multicolumn{12}{|l|}{ Family Pandeidae } \\
\hline Amphinema dinema (Péron \& Lesueur, 1810) & 7.0 & 157 & o & 154 & 1 & o & 2 & $34-16$ & $28-19$ & In/MZ/Pguá/Pin & 1 \\
\hline \multicolumn{12}{|l|}{ Family Proboscidactylidae } \\
\hline Proboscidactyla ornata (McCrady, 1857$)$ & 9.2 & 131 & 2 & 26 & 102 & 1 & o & $33-16$ & $30-15$ & In/MZ/Pguá/Lar/Pin & 1,3 \\
\hline \multicolumn{12}{|l|}{ Family Rathkeidae } \\
\hline Podocorynoides minima (Trinci, 1903) & - & - & - & - & - & - & - & $30-10$ & $31-19$ & Pguá & 3 \\
\hline \multicolumn{12}{|l|}{ Suborder Capitata Family Corymorphidae } \\
\hline Corymorpha gracilis (Brooks, 1883) & 51.3 & 2739 & 246 & 1090 & 277 & 315 & 811 & $34-15$ & $30-20$ & In/MZ/Pguá/Lar/Pin & 1,3 \\
\hline Corymorpha forbesii(Mayer, 1894) & 2.7 & 27 & o & o & 1 & 26 & o & $30-21$ & $29-20$ & Lar/Pin & 1 \\
\hline Corymorpha januarii Steenstrup, 1855 & 1.6 & 5 & $\mathrm{o}$ & o & 2 & 1 & 2 & $30-21$ & $28-20$ & Pguá/Lar & 1 \\
\hline \multicolumn{12}{|l|}{ Family Moerisiidae } \\
\hline Moerisia inkermanica Paltschikowa-Ostroumowa, & - & - & - & - & - & - & - & $20-0$ & $30-24$ & $\mathrm{MZ}$ & 2,3 \\
\hline \multicolumn{12}{|l|}{ Family Corynidae } \\
\hline Stauridiosarsia reesi (Vannucci, 1956) & 7.0 & 19 & 10 & 3 & 6 & o & o & $33-20$ & $31-21$ & In/MZ/Pguá/Pin & 1 \\
\hline Coryneeximia Allman, 1859 & - & - & - & - & - & - & - & $15-10$ & - & $\mathrm{MZ}$ & 3 \\
\hline \multicolumn{12}{|l|}{ Family Tubulariidae } \\
\hline Ectopleura dumortierii van Beneden, 1844 & 31.9 & 950 & 150 & 696 & 88 & 14 & 2 & $34-16$ & $31-21$ & In/MZ/Pguá/Lar/Pin & 1,3 \\
\hline \multicolumn{12}{|l|}{ Order Leptothecata Suborder Conica Family Blackfordiidae } \\
\hline Blackfordia virginica Mayer, 1910 & 7.0 & 31 & 20 & 4 & 5 & 2 & o & $29-2$ & $28-20$ & MZ/Pguá/Lar & $1,2,3$ \\
\hline \multicolumn{12}{|l|}{ Family Cirrholovenidae } \\
\hline Cirrholovenia tetranema Kramp, 1959 & 2.2 & 4 & 1 & o & 2 & 1 & o & $31-20$ & $31-21$ & MZ/Pin & 1 \\
\hline \multicolumn{12}{|l|}{ Family Eirenidae } \\
\hline Eutima mira McCrady, 1857 & 2.2 & 6 & 5 & o & 1 & o & o & $28-14$ & $30-27$ & Pguá/Lar/Pin & 1 \\
\hline Helgicirrha sp. & 2.7 & 8 & $\mathrm{o}$ & 1 & o & 2 & 5 & 25 & 20 & Pguá & 1 \\
\hline
\end{tabular}


Table 1. Continued

\begin{tabular}{|c|c|c|c|c|c|c|c|c|c|c|c|}
\hline \multirow[t]{2}{*}{ Species } & \multirow[b]{2}{*}{$\begin{array}{l}\text { FC } \\
(\%)\end{array}$} & \multicolumn{6}{|c|}{ Number of individuals } & \multirow[b]{2}{*}{ S } & \multirow[b]{2}{*}{$\mathrm{T}\left({ }^{\circ} \mathrm{C}\right)$} & \multirow[b]{2}{*}{ PES sector } & \multirow[b]{2}{*}{$\begin{array}{l}\text { Data } \\
\text { Source }\end{array}$} \\
\hline & & Total & $\begin{array}{c}\text { Summer } \\
2012\end{array}$ & $\begin{array}{c}\text { Winter } \\
2012\end{array}$ & $\begin{array}{c}\text { Summer } \\
2013\end{array}$ & $\begin{array}{c}\text { Winter } \\
2013\end{array}$ & $\begin{array}{c}\text { Summer } \\
2014\end{array}$ & & & & \\
\hline \multicolumn{12}{|l|}{ Family Laodiceidae } \\
\hline Laodicea minuscula Vannucci, 1957 & 2.2 & 7 & 4 & 2 & o & o & 1 & $31-28$ & $30-24$ & MZ/Pguá/Pin & 1 \\
\hline \multicolumn{12}{|l|}{ Family Lovenellidae } \\
\hline Eucheilota duodecimalis A. Agassiz, 1862 & 51.3 & 1628 & 266 & 579 & 666 & 5 & 112 & $34-15$ & $31-19$ & In/MZ/Pguá/Lar/Pin & 1,3 \\
\hline Eucheilota paradoxica Mayer, 1900 & 12.4 & 104 & 7 & 91 & 1 & 0 & 5 & $33-20$ & $30-20$ & In/MZ/Pguá/Pin & 1,3 \\
\hline Eucheilota maculata Hartlaub, 1894 & 14.1 & 240 & o & o & o & 77 & 163 & $34-15$ & $30-20$ & MZ/Pguá/Lar/Pin & 1,3 \\
\hline \multicolumn{12}{|l|}{ Family Malagazziidae } \\
\hline Malagazzia carolinae (Mayer, 1900) & 1.1 & 6 & 2 & o & 4 & o & o & $24-16$ & 29 & Pguá & 1 \\
\hline \multicolumn{12}{|l|}{ Suborder Proboscoida } \\
\hline \multicolumn{12}{|l|}{ Family Campanulariidae } \\
\hline Obelia spp. ${ }^{a}$ & 80.5 & 8285 & 807 & 3011 & 2690 & 196 & 1581 & $34-15$ & $30-19$ & In/MZ/Pguá/Lar/Pin & 1,3 \\
\hline Clytia spp. ${ }^{\mathrm{a}}$ & 80.5 & 7609 & 1383 & 2688 & 3361 & 98 & 79 & $34-15$ & $31-19$ & In/MZ/Pguá/Lar/Pin & 1,3 \\
\hline \multicolumn{12}{|l|}{ Order Siphonophora } \\
\hline \multicolumn{12}{|l|}{ Suborder Calycophora Family Abylidae } \\
\hline Abylopsis tetragona (Otto, 1823) & 1.1 & 2 & o & 1 & 1 & o & o & $33-26$ & $29-24$ & In & 1 \\
\hline Family Diphyidae & & & & & & & & & & $\mathrm{In} / \mathrm{MZ}$ & \\
\hline Muggiaea kochii (Will, 1844) & 2.2 & 5 & o & 3 & o & 1 & 1 & $34-30$ & $24-21$ & & 1,5 \\
\hline \multicolumn{12}{|l|}{ Suborder Physonectae Family Agalmatidae } \\
\hline Nanomia bijuga (delle Chiaje, 1844) & 3.8 & 9 & 2 & 5 & o & 2 & o & $33-23$ & $31-20$ & In/MZ/Pguá/Pin & 1 \\
\hline \multicolumn{12}{|c|}{ Subclass Trachylina Order Limnomedusae Family Olindiasidae } \\
\hline Gossea brachymera Bigelow, 1909 & 1.6 & 4 & 1 & 3 & o & o & o & $33-28$ & $28-20$ & $\mathrm{MZ} / \mathrm{Pin}$ & 1 \\
\hline \multicolumn{12}{|l|}{ Family Olindiidae } \\
\hline Olindias sambaquiensis Müller, $1861^{\mathrm{b}}$ & - & - & - & - & - & - & - & - & - & Pguá & 1 \\
\hline Aglauropsis kawari Moreira \& Yamashita, 1972 & 0.5 & 1 & 0 & o & o & o & 1 & 32 & 27 & In & 1 \\
\hline \multicolumn{12}{|l|}{ Order Narcomedusae Family Cuninidae } \\
\hline Cunina octonaria McCrady, 1857 & 10.2 & 67 & 0 & 58 & 9 & o & o & $34-17$ & $28-19$ & In/MZ/Pguá/Lar/Pin & 1 \\
\hline \multicolumn{12}{|l|}{ Family Solmarisidae } \\
\hline Solmaris sp. & 13.0 & 285 & 11 & 11 & o & 24 & 239 & $34-23$ & $28-20$ & In/MZ/Pguá/Pin & 1 \\
\hline \multicolumn{12}{|l|}{ Order Trachymedusae Family Geryoniidae } \\
\hline Liriope tetraphylla (Chamysso \& Eyesenhardt, 1821) & 63.8 & 5547 & 707 & 3100 & 780 & 778 & 182 & $34-17$ & $31-10$ & In/MZ/Pguá/Lar/Pin & $1,3,4,5$ \\
\hline Geryonia proboscidalis (Forsskål, 1775) & - & - & - & - & - & - & - & - & - & MZ/Lar & 4 \\
\hline \multicolumn{12}{|l|}{ Family Rhopalonematidae } \\
\hline Aglaura hemistoma Péron \& Lesueur, 1810 & 0.5 & 1 & o & o & o & 1 & o & 34 & 21 & $\mathrm{MZ}$ & 1 \\
\hline
\end{tabular}

Damaged and unidentifiable organisms $(\mathrm{N}=173)$ were not included. Salinity $(\mathrm{S})$ and temperature $\left(\mathrm{T}\right.$, in $\left.{ }^{\circ} \mathrm{C}\right)$ range and PES sector occurrence of each species in the present study and in previous studies are also shown. ${ }^{\text {a }}$ Species whose polyps have also been recorded in PES.

'bpecimen only sighted. Data source: 1=present study; $2=$ Nogueira Júnior \& Oliveira (2006); $3=$ Bardi (2011); 4=Montú \& Cordeiro (1988); $5=$ Lopes et al. (1998); 6=Haddad et al. (2014); Bettim \& Haddad (2017). In, inlets; MZ, mixing zone; Pguá, Paranaguá Bay; Lar, Laranjeiras Bay; Pin, Pinheiros Bay. 


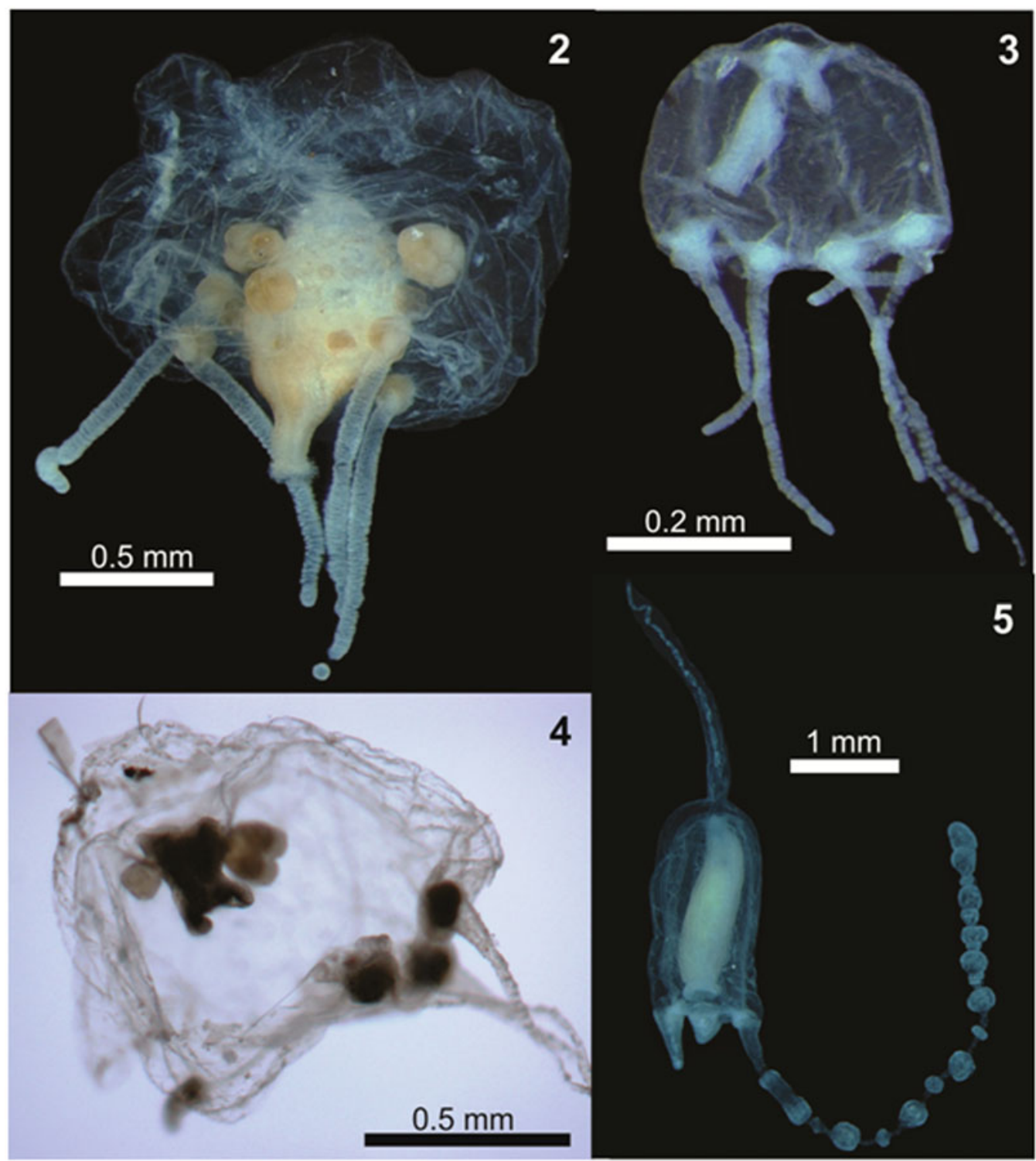

Fig. 2 - 5. Examples of planktonic hydrozoans from Paranaguá Estuarine System, southern Brazil. Cnidostoma fallax, lateral view (2); Podocoryna loyola, lateral view (3); Proboscidactyla ornata, lateral view (4) and Corymorpha gracilis, lateral view (5).

recorded here. Four taxa, namely Clytia spp. (Figure 9), Obelia spp., Solmaris sp. and Helgicirrha sp. (Figure 8), could not be identified to species level since the latter is probably an undescribed species, and all the other genera have taxonomic problems (Nagata et al., 2014a). All the planktonic hydrozoan species found here have already been recorded for the Brazilian coast (Oliveira et al., 2016), but 19 species are new records for PES and nine for Paraná State (Table 1; Nagata et al., 2014a). Although these new records fill gaps in their distribution their occurrence was expected, since polyps and/or medusae of them have been found to the south and/or north of the PES (Oliveira et al., 2016).

The accumulated number of sampled species nearly stabilized (Figure 15), and the diversity recorded here ( $34 \mathrm{spp}$.) is quite similar to the estimators that reached up to 36 in the Jackknife 2, and is considerably greater than that estimated by the Chao 2 (Figure 15). Therefore, the diversity of planktonic hydrozoans estimated here can be considered robust, and only a few additional species are likely to be found in future studies. Yet, the total species richness reported probably still is slightly underestimated due to the difficulty of identifying the different species of Clytia and Obelia based on medusa morphology, the notorious fragility of planktonic hydrozoans which result in damaged and unidentifiable individuals (even when relatively few) that could represent additional species. Moreover, the use of different gear types also may help to find additional species such as Rhacostoma atlanticum and Olindias sambaquiensis, not sampled here but known to commonly occur in coastal waters nearby and occasionally entering estuaries (Nogueira Júnior et al., 2010; Nogueira Júnior, 2012). These species are usually large-sized (reaching up to $>40 \mathrm{~mm}$ ) and thus rarely sampled in standard zooplankton nets as used here (Nagata et al., 2014a). In fact, O. sambaquiensis has been observed a few times in the PES tidal channels in samples with larger nets not included here (LSN, personal observations). Sampling in other seasons also could result in additional species. For instance, Octophialucium haeckeli was not found here at PES perhaps due to absence 


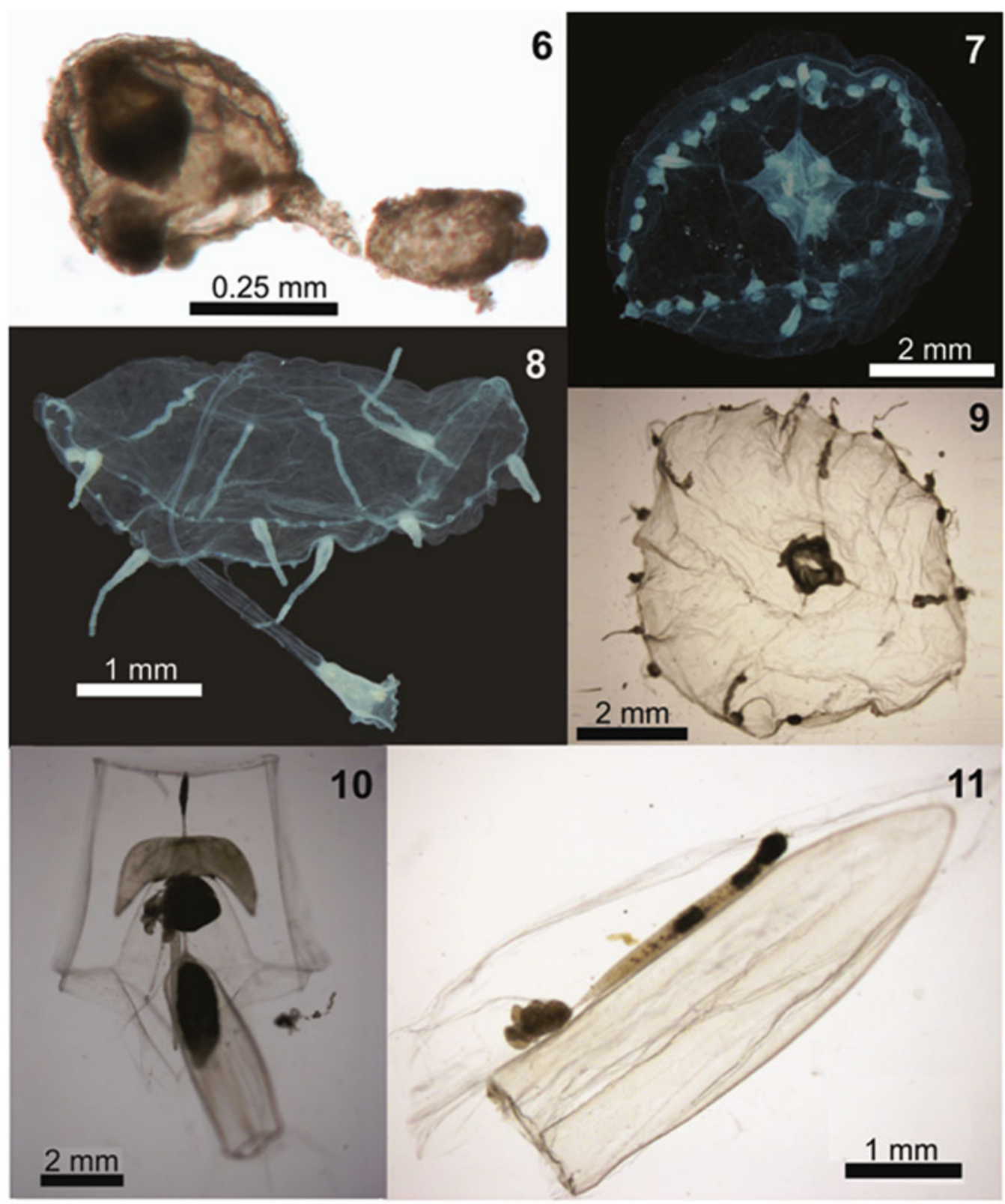

Fig. 6- 11. Examples of planktonic hydrozoans from Paranaguá Estuarine System, southern Brazil. Corymorpha forbesii, lateral view (6); Malagazzia carolinae, oral view (7); Helgicirrha sp., lateral view (8); Clytia spp., oral view (9); Abylopsis tetragona eudoxid (10) and Muggiaea kochii, lateral view (11).

of sampling in autumn and/or spring seasons when this medusa was found in more southerly estuarine waters (Nogueira Júnior et al., 2015). Nevertheless, the other three species exclusively found in these seasons (see Nogueira Júnior et al., 2015: their supplementary online material table 1), namely Amphinema dinema, Gossea brachymera and Abylopsis tetragona, were sampled in the present study (Table 1).

The limited literature data available indicate that four additional species can be included in the PES planktonic hydrozoan checklist: Moerisia inkermanica Paltschikowa-Ostroumowa, 1925, Coryne eximia Allman, 1859, Podocorynoides minima (Trinci, 1903) and Geryonia proboscidalis (Forsskål, 1775) (Montú \& Cordeiro, 1988; Nogueira Júnior \& Oliveira, 2006; Bardi, 2011; Table 1), that along with O. sambaquiensis (see above) totals 39 species. The general species composition of planktonic hydrozoans from PES is a highly diverse estuarine fauna, with many brackish-water tolerant species. Typical examples are Cnidostoma fallax, Moerisia inkermanica and Malagazzia carolinae which are more abundant or exclusive inside estuaries (Teixeira-Amaral et al., 2017; Nogueira Júnior et al., 2018; Nogueira Júnior \& Silva Nascimento, 2018) rather than on the adjacent shelf (Vannucci, 1957, 1963; Nagata et al., 2014a).

The PES fauna is quite similar to other tropical/subtropical estuaries from the south-western Atlantic (Nogueira Júnior et al., 2018) and elsewhere (e.g. Vannucci et al., 1970; Santhakumari et al., 1997, 1999). This high diversity is similar to the few other comprehensively sampled nearby estuaries (Nogueira Júnior et al., 2018), but contrasts with the general view that estuarine hydrozoan fauna is impoverished (Calder, 1971; Santhakumari et al., 1997, 1999). In fact, tropical/subtropical estuarine systems in the southwestern Atlantic seem to harbour more hydromedusae 


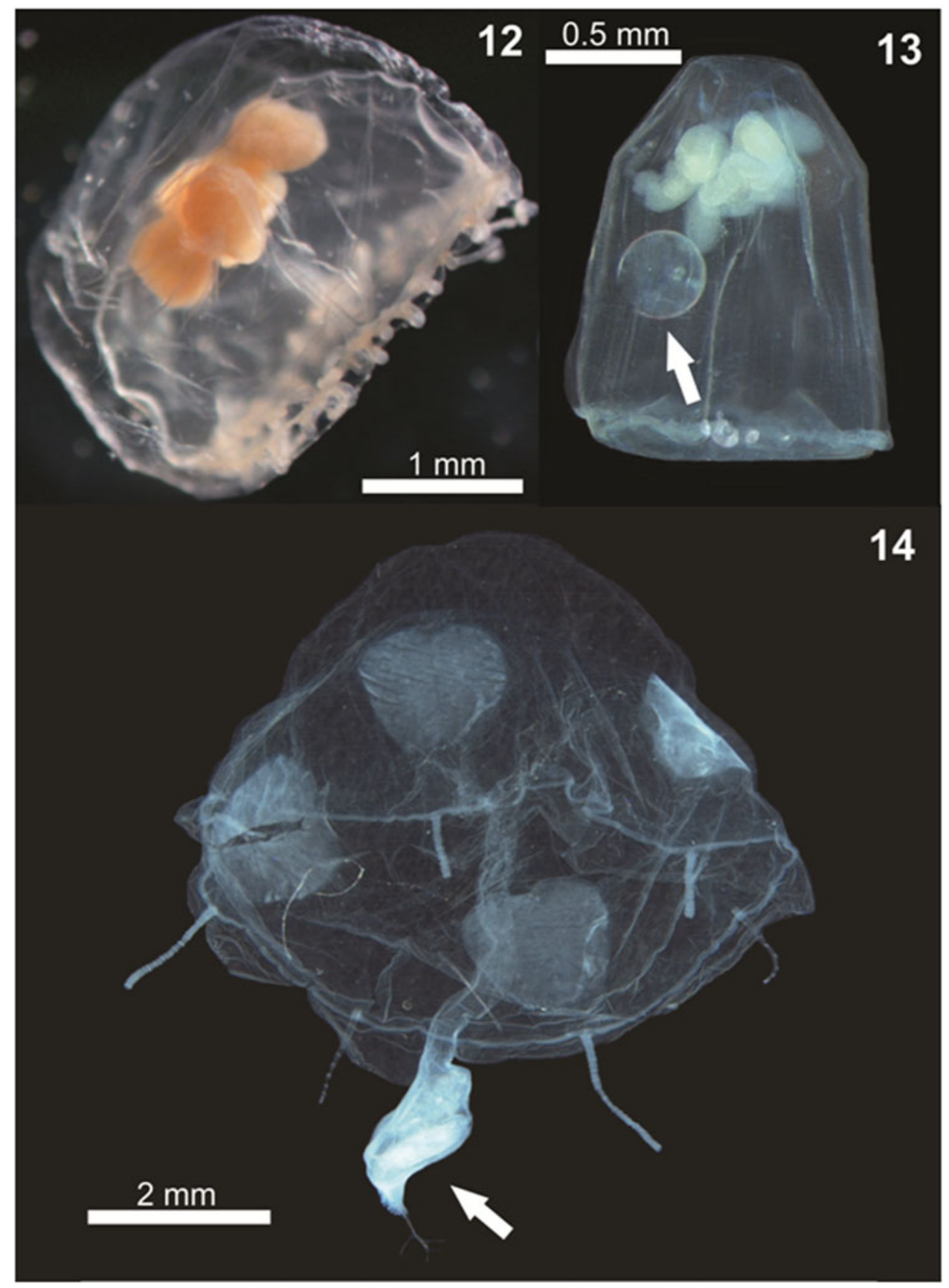

Fig. 12-14. Examples of planktonic hydrozoans from Paranaguá Estuarine System, southern Brazil. Aglauropsis kawari, lateral view (12); Aglaura hemistoma, lateral view, white arrow indicates a diatom inside the umbrella (13) and Liriope tetraphylla, lateral view, white arrow indicates copepods as possible prey in digestion process (14).

species (e.g. Nogueira Júnior , 2012 - 36 spp.; present study 36 spp.; Aguilar et al., 2015 - 35 spp.) than adjacent shelf regions (e.g. Vannucci, 1957 - 27 spp.; Vannucci, 1963 17 spp.; Nagata et al., 2014a, b - 22 spp.). These observations emphasize the necessity of comprehensive sampling of other tropical/subtropical estuaries from the south-western Atlantic and worldwide. These could potentially harbour high diversity and are commonly poorly studied, since most previous studies focus on temperate estuaries commonly with considerably lower diversity (e.g. Calder, 1971; Petrova et al., 2011; Pestorić et al., 2012; Vansteenbrugge et al., 2015; Zuo et al., 2016; Dutto et al., 2017).
Meroplanktonic species represented $79 \%$ of total PES planktonic hydrozoans (30 spp.), as is typical from tropical and subtropical estuaries (Navas Pereira, 1980; Santhakumari et al., 1997, 1999; Nogueira Júnior, 2012). Meroplanktonic Anthoathecata from PES represent $24.6 \%$ of those recorded from Brazil and $\mathbf{1 5 . 7 \%}$ from the South Atlantic, while meroplanktonic Leptothecata represent $22 \%$ and $18.6 \%$, and Limnomedusae represent 40 and $22.2 \%$, respectively (Bouillon, 1999; Oliveira et al., 2016). These proportions are quite high considering that PES $\left(\sim 550 \mathrm{~km}^{2}\right)$, harbours nearly a quarter of all meroplanktonic hydrozoans so far recorded from the $>8000 \mathrm{~km}$ of Brazilian coastline. 


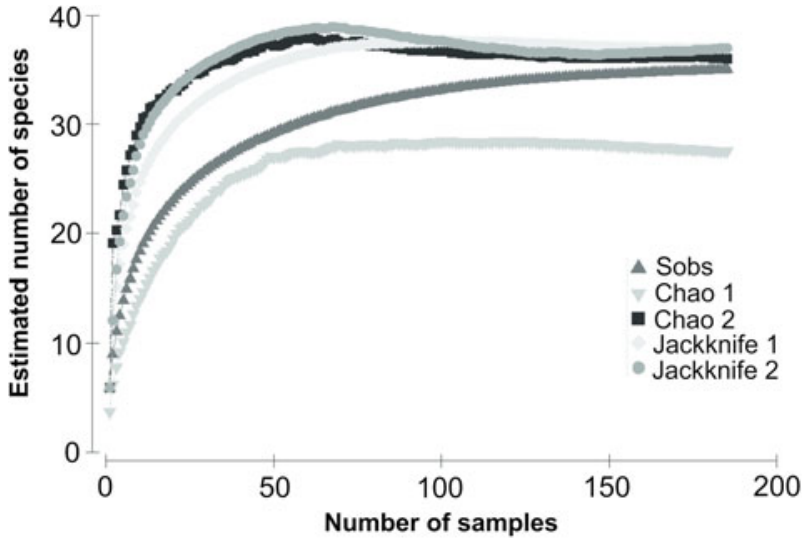

Fig. 15. Accumulation curves of richness estimators from planktonic hydrozoan species in Paranaguá Estuarine System, southern Brazil.

On the other hand, holoplanktonic hydrozoans from PES (i.e. Siphonophorae, Narcomedusae and Trachymedusae) represent only $\sim 7$ and $5 \%$ of all species from Brazil and the South Atlantic, respectively (Bouillon, 1999; Pugh, 1999; Oliveira et al., 2016). With the exception of Liriope tetraphylla, present in $64 \%$ of the samples and representing $11 \%$ of all hydrozoans sampled, all other holoplanktonic species presented relatively low frequencies of occurrence and abundance. They were mostly found in the outer sectors of the estuary, in the inlets, mixing zone and outer stations of Pinheiros Bay (Table 1). These observations suggest their populations are not resident and were probably advected from adjacent shelf waters where they are common and abundant (Vannucci, 1957, 1963; Nagata et al., 2014b; Nogueira Júnior et al., 2014).

The additional records of Dipurena sp. (Bardi, 2011) and Aglantha sp. (Montú \& Cordeiro, 1988) from PES were not considered, pending confirmation due to taxonomic uncertainties. The genus Dipurena is no longer accepted, and the species were moved either to the genus Slabberia or Stauridiosarsia (Schuchert, 2016). Moreover, Corynidae medusae are very similar to each other, particularly when juveniles, and Bardi (2011) does not state the reasons for identifying the three individuals only at the generic level (i.e. juveniles, damaged, not exactly fitting any known description). Since voucher, illustrations or descriptions of the studied individuals were not provided (Bardi, 2011) a critical re-analysis of the identification is not possible. Yet, we suspect that the Dipurena sp. record from PES may be juveniles and/or damaged Staurodiosarsia reesii, which is commonly found on South Brazilian Bight estuaries (Vannucci, 1957; Nogueira Júnior et al., 2018) including PES (present study; Table 1) and not recorded by Bardi (2011). The record of Aglantha sp. (Montú \& Cordeiro, 1988) is also doubtful (Nagata et al., 2014a) because it is typically an oceanic genus (Bouillon, 1999) and is probably a misidentification of Aglaura hemistoma (Figure 13), which is roughly similar and commonly found in the adjacent shallow shelf (Nagata et al., 2014a, b), occasionally with a few individuals entering the estuary, as found here (Table 1).

Cnidostoma fallax (Figure 2) was the most numerous species, with 19,455 individuals sampled, followed by Obelia spp. (8285 individuals), Clytia spp. (7609), Liriope tetraphylla (Figure 14; 5547), Corymorpha gracilis (2739) and Eucheilota duodecimalis (1628), all of them sampled both in summer and winter campaigns and in all PES sectors (Table 1). Some other species were frequently captured ( $>_{15} \%$ of samples), but were not so abundant $(<1000$ individuals), such as Ectopleura dumortierii, actinula larvae, Bougainvillia muscus and Podocoryna loyola (Figure 3).

The high dominance of $C$. fallax in the present study is noteworthy. This is in contrast to results from the PES in the 1980s (Montú \& Cordeiro, 1988), 1990s (Lopes, 1997; Lopes et al., 1998) and 200os (Bardi, 2011) when L. tetraphylla was the dominant hydromedusa, followed by Obelia spp., Clytia spp. or C. gracilis, and C. fallax was not present at all (Figure 16). In fact, L. tetraphylla, Obelia and Clytia have historically been the dominant hydromedusae in open shallow coastal and estuarine environments from the South Brazilian Bight (Vannucci, 1957, 1963; Teixeira et al., 1965; Navas-Pereira, 1980; Bardi, 2011; Nogueira Júnior, 2012; Nagata et al., 2014a, b; Nogueira Júnior et al., 2014, 2018). It is difficult to explain the reasons for such a replacement in the dominant species, particularly due to the poor historical knowledge of the Brazilian hydromedusan fauna, but unexpected high abundances of $C$. fallax have also recently been recorded at Patos Lagoon (Teixeira-Amaral et al., 2017). Considering that the presence of $C$. fallax in the south-western Atlantic has only recently been detected, and now is known to occur in many estuaries along Brazilian coast between $\sim 24$ and $34^{\circ} \mathrm{S}$ (Teixeira-Amaral et al., 2017; Nogueira Júnior et al., 2018; present study), two mutually excluding hypotheses may be proposed:

(i) C. fallax may have been overlooked in the few previous studies of these estuaries, either due to taxonomic uncertainties and/or to the low abundances of the species. Although most of these historical estuarine studies focused on the zooplankton as a whole and the most abundant taxa such as copepods, some focused on or attempted to identify the estuarine Brazilian hydromedusae including a few with relatively satisfactory spatial and temporal coverage (Vannucci, 1957; Teixeira et al., 1965; Montú \& Cordeiro, 1988; Lopes, 1997; Bardi, 2011), and none has recorded C. fallax which is a very peculiar and easily identifiable species.

(ii) C. fallax appeared recently, perhaps introduced from tropical Atlantic African coastal estuaries which are the

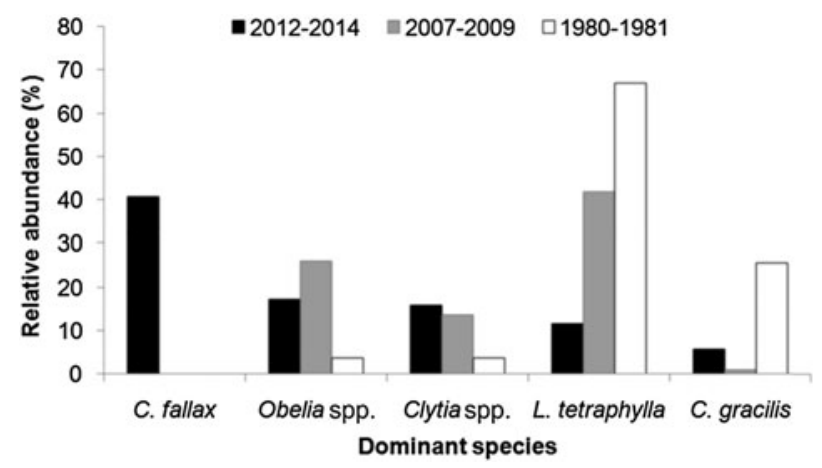

Fig. 16. Comparisons of the relative abundance (\%) of dominant hydromedusae species from Paranaguá Estuarine System, southern Brazil from different periods. Data source: (a) 1980-1981 - taken from Montú \& Cordeiro, 1989; (b) 2007-2009 - taken from Bardi, 2011; (c) 2012-2014 present study. Lopes et al. (1998) did not provide quantitative data on hydromedusae but comment that Liriope tetraphylla was the dominant species. 
location of all historical records of the species (Vanhöffen, 1911; Picard \& Rahm, 1954 as Archaeoceania tournieri; Kramp, 1959). The evidence for this hypothesis would be the lack of previous records in spite of studies (albeit few) on these very same estuaries (e.g. Teixeira et al., 1965; Montú \& Cordeiro, 1988; Lopes, 1997; Bardi, 2011) where the species is currently known to occur (see references above). Although speculative, it is not unlikely that C. fallax is an introduced species considering that along with its recent discovery, all sites with known populations are brackish water environments near ports (e.g. Vanhöffen, 1911; Picard \& Rahm, 1954; Kramp, 1959; Teixeira-Amaral et al., 2017; this study), and the high national and international ship traffic in PES could be a potential vector, along with other cnidarian and noncnidarian exotic species (e.g. Neves \& Rocha, 2008; Van Ofwegen \& Haddad, 2011; Haddad et al., 2014; Bettim \& Haddad, 2017).

Independently of the origin of the $C$. fallax population (hypothesis $i$ or $i i$ above), its massive presence during the present study is noteworthy and suggests a replacement of a historically dominant species. In the present study C. fallax dominated the total abundance and the typical previous dominant species L tetraphylla ranks fourth, representing only $11 \%$ of all hydromedusae. This contrasts with previous studies where L. tetraphylla has always been dominant, representing between 42 and $67 \%$ of the population (Figure 16). Considering that C. fallax and L. tetraphylla probably have different roles in the ecosystem - the former is meroplanktonic small-sized $\left(<_{1} \mathrm{~mm}\right)$ and probably eats very small organisms and the latter is holoplanktonic larger-sized $(>5 \mathrm{~mm})$ and eats larger organisms like copepods (Figure 14), this shift in the dominance of these species could change the energy pathways of local food webs and the planktonic assemblage structure.

Species which produce medusa buds such as C. fallax can rapidly increase their population levels by asexual reproduction, typically under warm and specific temperature conditions (Carré \& Carré, 1990; Kawamura \& Kubota, 2008). Thus, we question which environmental factors may have contributed to $C$. fallax population increase and what impacts it may cause. It occurred over three consecutive summers in the present study, but was mainly captured in summer 2012 ( $>16,000$ medusae), which coincides with the swarm recorded from Patos Lagoon, $\sim 500 \mathrm{~km}$ south (Teixeira-Amaral et al., 2017); also suggesting that the changes reported here may not be restricted to PES. A hypothesis for the simultaneous occurrence of C. fallax swarms in these Brazilian estuaries may be related to large inter-annual variations in river discharge, circulation and salinization processes associated with ENSO events. March 2012 was at the end of a La Niña event (NOAA, 2017). On the southern Brazilian coast, these events are usually associated with lower precipitation and freshwater outflow, and higher salinity values (Grimm et al., 1998; Möller \& Fernandes, 2010; Nascimento Júnior \& Sant'Anna Neto, 2015) and maybe this condition favoured a C. fallax outburst.

Although C. fallax abundance diminished from summer 2012 to the summer of 2014, it remained among the dominant species (Table 1), maintaining high levels and apparently persistent populations inside PES. Indeed, specimens of different sizes and development were observed every summer. We do not know if this change in assemblage structure is permanent or if it is part of an erratic and intermittent massive occurrence commonly registered for jellyfish around the world (e.g. Buecher et al., 1997; Malej \& Malej, 2004; Boero et al., 2008; Licandro et al., 2012; Van Walraven et al., 2015), including some invasive species (Greve, 1994; Riisgård et al., 2012; Yilmaz, 2015). Thus, further monitoring programmes would be welcome to check if this peculiar hydrozoan species will maintain high population levels in the medium- to long-term. Moreover, future studies assessing the biology and ecology of C. fallax (e.g. genetics and evolution, life cycle constraints, preferential temperature and salinity ranges, effects of climatic events, reproductive potential and feeding rates) will be important to assess which environmental factors contributed to its population outburst as reported here, and what impacts it may cause. The life cycle of C. fallax is not known and its taxonomy is arguable and it was suggested to belong to the families Oceaniidae (Picard \& Rahm, 1954), Cytaeididae (Kramp, 1961) and Hydractiniidae where it is currently placed (Schuchert, 2016). In any case, it probably has a polyp stage (e.g. Bouillon et al., 2006) and therefore life-cycle studies and factors affecting its potential benthic stage should also be considered.

\section{CDNCLUSIONS}

The present study constitutes a comprehensive survey of planktonic hydrozoans from PES, a Natural World Heritage site. Currently, a total of 39 species have been recorded from PES, 35 of them studied here. Given the high sampling effort employed (185 samples analysed and $>49$,000 organisms examined), it can be considered that the planktonic hydrozoan fauna from PES is relatively well represented in the present study, as also suggested by the species accumulation curves (Figure 15), although a few further species are likely to be found. The high biodiversity observed herein indicates that the estuary harbours a diverse aquatic fauna, being important for regional biodiversity conservation. The most abundant species $(\sim 40 \%$ of all specimens $)$ was unexpectedly Cnidostoma fallax, indicating changes in the assemblage structure compared to previous decades when L. tetraphylla has always been dominant. It is difficult to deduce the reasons for these changes in the planktonic hydrozoan assemblage structure due to the low number of historical studies for Brazilian estuaries. The complete absence of $C$. fallax from these previous studies from PES and nearby estuaries may suggest it has been recently introduced, although it may have been overlooked. Further studies including molecular analysis (see for instance Harrison et al., 2013 for Blackfordia virginica) could help to clarify the origins of such populations. In any case, changes in the structure of the hydromedusae assemblage were clear when compared to previous decades when L. tetraphylla has always dominated. Such replacement may lead to changes in the local pelagic assemblage and food chain. Although $C$. fallax was abundantly sampled through three consecutive years, future surveys are important to check the permanency and the abundance levels of this population.

\section{ACKNOWLEDGEMENTS}

We are grateful for the Taxonline - Rede Paranaense de Coleções Biológicas, University of Paraná, for the resources 
used in the species photographs and to Franciele Betim for the assistance with the photographs; and Ronei Derengoski, Abrão Pereira de Campos, Bianca Salvador, Laura Straub, Yasmim Freitas and Fernanda de Felipe, partners in the fieldwork. We thank also referees for comments that substantially improved the paper.

\section{FINANCIAL SUPPORT}

This study is part of Biomar project, which was financed by Fundação Grupo $\mathrm{O}$ Boticário de Proteção à Natureza (BLooo2_20111). The authors acknowledge Coordenação de Aperfeiçoamento de Pessoal de Nível Superior (Capes; http://www.capes.gov.br) for funding a Master of Science scholarship for LSN (2014-2016) and Conselho Nacional de Pesquisa (CNPq; http://www.cnpq.br) for funding a scientific initiation scholarship for EMV (2014-2015).

\section{REFERENCES}

Aguilar M.I.T., Costa B.S.P., Miyashita L.K., Brandini F. and Nogueira Júnior M.N. (2015) Diversity of gelatinous zooplankton (Cnidaria Ctenophora, Chaetognatha and Tunicata) from the Cananéia-Iguape estuarine system (São Paulo, Brazil) Sixtieth Congreso Latino americano de Ciencias del Mar - Colacmar, Santa Marta, Colômbia, 18 22 October 2015.

Bardi J. (2011) Comunidades de hidrozoários (Cnidaria) estuarinos do sudeste e sul do Brasil. PhD thesis. Universidade de São Paulo, São Paulo, Brazil.

Bettim A.L. and Haddad M.A. (2017) Seasonal recruitment of the hydroid Podocoryna loyola (Hydractiniidae) in the Paranaguá Bay, South of Brazil. Marine Biology Research 13, 560-572.

Boero F., Bouillon J., Gravili C., Miglietta M. P., Parsons T. and Piraino S. (2008) Gelatinous plankton: irregularities rule the world (sometimes). Marine Ecology Progress Series 356, 299-310.

Bouchereau J.L., Chaves P. and Monti D. (2008) Factors structuring the ichthyofauna assemblage in a mangrove lagoon (Guadeloupe, French West Indies). Journal of Coastal Research 24, 969-982.

Bouchet P. (2006) The magnitude of marine biodiversity. In Duarte C.M. (ed.) The exploration of marine biodiversity: scientific and technological challenges. Bilbao, Fundación BBVA, pp. 31-64.

Bouillon J. (1999) Hydromedusae. In Boltovsky D. (ed.) South Atlantic zooplankton. Leide: Backhuys Publishers, pp. 385-465.

Bouillon J., Gravili C., Pages F., Gili J.M. and Boero F. (2006) An introduction to hydrozoa. Memoires du Museum National d'Histoire Naturelle 194, 1-591.

Bouillon J., Medel M.D., Pagès F., Gili J.M., Boero F. and Gravili C. (2004) Fauna of the Mediterranean Hydrozoa. Scientia Marina $68\left(\mathrm{~S}_{2}\right), 5-438$.

Buecher E., Goy J., Planque B., Etienne M. and Dallot S. (1997) Long-term fluctuations of Liriope tetraphylla in Ville Franche Bay between 1966 and 1993 compared to Pelagia noctiluca populations. Oceanologica Acta 20, 145-157.

Calder D. (1971) Hydroids and hydromedusae of southern Chesapeake Bay. Virginia Institute of Marine Science, Special Papers in Marine Science 1, 1-125.

Carlton J.T. (1996) Pattern, process, and prediction in marine invasion ecology. Biological Conservation 78, 97-106.
Carlton J.T. (2000) Global change and biological invasions in the oceans. In Mooney H.A. and Hobbs R.J. (eds) Invasive species in a changing world. Covelo, CA: Island Press, pp. 31-53.

Carré D. and Carré C. (1990) Complex reproductive cycle in Eucheilota paradoxica (Hydrozoa: Leptomedusae): medusae, polyps and frustules produced from medusa stage. Marine Biology 104, 303-310.

Clarke K.R and Gorley R.N. (2006) PRIMER v6 user manual/tutorial. Plymouth routines in multivariate research. Plymouth: Plymouth Marine Laboratory.

Costello M.J., Wilson S. and Houlding B. (2013) More taxonomists describing significantly fewer species per unit effort may indicate that most species have been discovered. Systematic Biology 62, 616-624.

Cremer M.J., Morales P.R.D and Oliveira T.M.N. (2006) Diagnóstico ambiental da Baía da Babitonga. Joinville: Editora da Univille.

Dolan J.R. and Gallegos C.L. (2001) Estuarine diversity of tintinnids (planktonic ciliates). Journal of Plankton Research 23, 1009-1027.

Dulvy N.K., Sadovy Y. and Reynolds J.D. (2003) Extinction vulnerability in marine populations. Fish and Fisheries 4, 25-64.

Dutto M.S., Genzano G.N., Schiariti A., Lecanda J., Hoffmeyer M.S. and Pratolongo P.D. (2017) Medusae and ctenophores from the Bahía Blanca Estuary and neighboring inner shelf (Southwest Atlantic Ocean, Argentina). Marine Biodiversity Records 10, 14.

Gallardo B., Clavero M., Sánchez M.I. and Vilà M. (2016) Global ecological impacts of invasive species in aquatic ecosystems. Global Change Biology 22, 151-163.

Greve W. (1994) The 1989 German bight invasion of Muggiaea Atlantica. ICES Journal of Marine Science 51, 355-358.

Grimm A.M., Ferraz S.E.T. and Gomes J. (1998) Precipitation anomalies in southern Brazil associated with El Nino and La Niña events. Journal of Climate 11, 2863-2880.

Haddad M.A., Bettim A.L. and Miglietta M.P. (2014) Podocoryna loyola, n. sp. (Hydrozoa, Hydractiniidae): a probably introduced species on artificial substrate from southern Brazil. Zootaxa 3796, 494-506.

Haddad M.A. and Marques A.C. (2009) Cnidaria. In Ribeiro-Costa C.S. and Rocha R.M. (eds) Invertebrados, manual de aulas práticas. Ribeirão Preto: Holos, pp. 24-50.

Harrison G.F., Kim K. and Collins A.G. (2013) Low genetic diversity of the putatively introduced, brackish water hydrozoan, Blackfordia virginica (Leptothecata: Blackfordiidae), throughout the United States, with a new record for Lake Pontchartrain, Louisiana. Proceedings of the Biological Society of Washington 126, 91-102.

Kawamura M. and Kubota S. (2008) Influences of temperature and salinity on asexual budding by hydromedusa Proboscidactyla ornata (Cnidaria: Hydrozoa: Proboscidactylidae). Journal of the Marine Biological Association of the United Kingdom 88, 1601-1606.

Kramp P.L. (1959) Medusae mainly from the west coast of Africa. Memoirs Institut Royal des Sciences Naturelles de Belgique 3, 1-33.

Kramp P.L. (1961) Synopsis of the Medusae of the world. Journal of the Marine Biological Association of the United Kingdom 40, 1-469.

Licandro P., Souissi S., Ibanez F. and Carré C. (2012) Long-term variability and environmental preferences of calycophoran siphonophores in the Bay of Villefranche (north-western Mediterranean). Progress in Oceanography 97, 152-163.

Lopes R.M. (1997) Zooplâncton da Baía de Paranaguá: distribuição espacial, variação temporal e interações tróficas. $\mathrm{PhD}$ thesis. Universidade Federal do Paraná, Paraná, Brazil.

Lopes R.M., Vale R.D. and Brandini F.P. (1998) Zooplankton composition, abundance and spatial distribution in the estuarine complex of 
Paranaguá during winter 1993 and summer 1994. Revista Brasileira de Oceanografia 46, 195-211.

Malej A. and Malej A. Jr (2004) Invasion of the jellyfish Pelagia noctiluca in the Northern Adriatic: a non-success story. In Dumond H., Shiganova T.A. and Nierman U. (eds) Aquatic invasions in the Black, Caspian and Mediterranean Seas. Dordrecht: Kluwer Academic Publishers, pp. 273-285.

Marone E., Machado E.C., Lopes R.M. and Silva E.T. (2000) Paranaguá Bay estuarine complex, Paraná State. In Smith S.V., Dupra V., Marshall Crossland J.L. and Crossland C.J. (eds) Estuarine systems of the South American region: carbon, nitrogen and phosphorus fluxes. Texel: LOICZ Reports and Studies, p. 15.

Matsakis S. and Conover R.J. (1991) Abundance and feeding of medusae and their potential impact as predators on other zooplankton in Bedford Basin (Nova Scotia, Canada) during spring. Canadian Journal of Fisheries and Aquatic Sciences 48, 1419-1430.

Mills C.E. (1995) Medusae, siphonophores and ctenophores as planktivorous predators in changing global ecosystems. ICES Journal of Marine Science 52, 575-581.

Möller O.O. Jr and Fernandes E. (2010) Hidrologia e hidrodinâmica. In Seeliger U. and Odebrecht C. (eds) O Estuário da Lagoa dos Patos: Um Século de Transformações. Rio Grande: FURG, pp. 17-27.

Montú M. and Cordeiro T.A. (1988) Zooplâncton del complejo estuarial de la Bahía de Paranaguá. I: composición, dinamica de las especies, ritmos reprodutivos y acción de los fatores ambientales sobre lacomunidad. Nerítica $3,61-83$.

Nagata R.M., Nogueira Júnior M., Brandini F.P. and Haddad M.A (2014b) Spatial and temporal variation of planktonic cnidarian density in subtropical waters of the Southern Brazilian Bight Journal of the Marine Biological Association of the United Kingdom 94, 1387-1400.

Nagata R.M., Nogueira Júnior M. and Haddad M.A. (2014a) Faunistic survey of Hydromedusae (Cnidaria, Medusozoa) from the coast of Paraná State, Southern Brazil. Zootaxa 3768, 291-326.

Nascimento L. Júnior and Sant'Anna Neto J.L. (2015) Contribuição aos estudos da precipitação no estado do paraná: a oscilação decadal do pacífico-ODP. Revista Raega 35, 314-343.

Navas-Pereira D. (1980) Hydromedusae of the Bay of Sepetiba (Rio de Janeiro, Brazil). Revista Brasileira de Biologia 40, 817-824.

Neves C. S. and Rocha R.M.D. (2008) Introduced and cryptogenic species and their management in Paranaguá Bay, Brazil. Brazilian Archives of Biology and Technology 51, 623-633.

NOAA (2017) National Oceanic and Atmospheric Administration. Climate Prediction Center, Cold \& Warm Episodes by Season. Available at http://www.cpc.ncep.noaa.gov/products/analysis_monitoring/ensostuff/ensoyears.shtml.

Noernberg M.A., Lautert L.F.C., Araújo A.D., Marone E., Angellotti R. Netto J.P.B. Júnior and Krug L.A. (2006) Remote sensing and GIS integration for modelling the Paranaguá estuarine complex - Brazil. Journal of Coastal Research 39, 1627-1631.

Nogueira Júnior M. (2012) Gelatinous zooplankton fauna (Cnidaria, Ctenophora and Thaliacea) from Baía da Babitonga (southern Brazil). Zootaxa 3398, 1-21.

Nogueira Júnior M., Brandini F.P. and Codina J.C. (2014) Distribution of planktonic cnidarians in response to South Atlantic Central Water intrusion in the South Brazilian Bight. Continental Shelf Research 89, 93-102.

Nogueira Júnior M., Nagata R.M. and Haddad M.A. (2010) Seasonal variation of macromedusae (Cnidaria) at North Bay, Florianópolis, southern Brazil. Zoologia 27, 377-386.
Nogueira Júnior M., Nascimento L.S., Maciel P.V., Tilbert S. and Oliveira L.D. (2018) Diversity, species composition and assemblage dynamics of estuarine gelatinous and semi-gelatinous zooplankton from Brazil. In Hoffmeyer M.S., Sabatini M.E., Brandini F.P., Calliari D. and Santinelli N. (eds) Plankton ecology of the Southwestern Atlantic - from the subtropical to the subantarctic realm. Dordrecht: Springer, pp. 375-412.

Nogueira Júnior M. and Oliveira J.S. (2006) Moerisia inkermanica Paltschikowa-Ostroumova (Hydrozoa; Moerisidae) e Blackfordia virginica Mayer (Hydrozoa; Blackfordiidae) na Baía de Antonina, Paraná, Brasil. Pan-American Journal of Aquatic Science 1, 35-42.

Nogueira Júnior M., Pukanski L.E.M. and Souza-Conceição J.M. (2015) Mesh size effects on assessments of planktonic hydrozoan abundance and assemblage structure. Journal of Marine Systems 144, 117-126.

Nogueira Júnior M. and Nascimento L.S. (2018) The ecology and developmental changes of meristic characters of the medusa Malagazzia carolinae (Hydrozoa: Leptothecata) from subtropical Southwestern Atlantic estuaries. Zoologischer Anzeiger 274, 34-45.

Oliveira O.M., Miranda T.P., Araujo E.M., Ayón P., Cedeño-Posso C.M., Cepeda-Mercado A.A., Córdova P., Cunha A.F., Genzano G.N., Haddad M.A., Mianzan H.W., Migotto A.E., Miranda L.S., Morandini A.C., Nagata R.M., Nascimento K.B., Nogueira Júnior M., Palma S., Quiñones J., Rodriguez C.S., Scarabino F., Schiariti A., Stampar S.N., Tronolone V.B. and Marques A.C. (2016) Census of Cnidaria (Medusozoa) and Ctenophora from South American marine waters. Zootaxa 4194, 1-256.

Paiva C.G., Chaves P.T.C. and Araújo M.E. (2013) Distribution of estuarine fish fauna along coast of Brazil. Tropical Oceanography 41, 1-36.

Pestorić B., Krpo-Ćetković J., Gangai B. and Lučić D. (2012) Pelagic cnidarians in the Boka Kotorska Bay, Montenegro (South Adriatic). Acta Adriatica 53, 91-392.

Petrova E.A., Dautova T.N. and Shkoldina L.S. (2011) Species composition, seasonal dynamics of quantities and spatial distribution of hydromedusae (Cnidaria: Hydrozoa) in Vostok Bay of the Sea of Japan. Russian Journal of Marine Biology 37, 111-122.

Picard J. and Rahm U. (1954) Archaeoceania n.g. tournieri n. sp. Une nouvelle Anthoméduse de la famille des Oceaniidae, provenant de lalagune Ebrié (Côte d'Ivoire). Acta Tropica 11, 303-307.

Pugh P.R. (1999) Siphonophorae. In Boltovsky D. (ed.) South Atlantic zooplankton. Leide: Backhuys Publishers, pp. 467-511.

Riisgård H.U., Madsen C.V., Barth-Jensen C. and Purcell J.E. (2012) Population dynamics and zooplankton-predation impact of the indigenous scyphozoan Aurelia aurita and the invasive ctenophore Mnemiopsis leidyi in Limfjorden (Denmark). Aquatic Invasions 7, 147-162.

Santhakumari V., Ramaiah N. and Nair V.R. (1997) Ecology of hydromedusae from Bombay Harbour-Thana and Bassein Creek estuarine complex. Indian Journal of Marine Sciences 26, 162-168.

Santhakumari V., Tiwari L.R. and Nair V.R. (1999) Species composition, abundance and distribution of hydromedusae from Dharamtar estuarine system, adjoin Bombay harbor. Indian Journal of Marine Sciences 28, 158-162.

Seguro I., García C.M., Papaspyrou S., Gálvez J.A., García-Robledo E., Navarro G., Soria-Píriz S., Aguilar V., Lizano O.G., Morales-Ramírez A. and Corzo A. (2015) Seasonal changes of the microplankton community along a tropical estuary. Regional Studies in Marine Science 2, 189-202.

Schuchert P. (2016) World Hydrozoa database. Available at http://www. marinespecies.org/hydrozoa. 
Teixeira C., Tundisi J. and Kutner M.B. (1965) Plankton studies in a mangrove environment II: the standing stock and some ecological factors. Boletim do Instituto Oceanográfico 14, 13-41.

Teixeira-Amaral P., Amaral W.J.A., de Ortiz D.O., Agostini V.O. and Muxagata E. (2017) The mesozooplankton of the Patos Lagoon Estuary, Brazil: trends in community structure and secondary production. Marine Biology Research 13, 48-61.

UNESCO (2016) Atlantic forest south-east reserves, 1999. Paris: United Nations Educational, Scientific and Cultural Organization. Available at http://whc.unesco.org/en/list/893.

Vanhöffen E. (1911) Die Anthomedusen und Leptomedusen der Deutschen Tiefsee-Expedition 1898-1899. Wissenschftliche Ergebnisse der Deutschen Tiefsee-Expedition Valdivia 19, 193-233.

Vannucci M. (1957) On Brazilian Hydromedusae and their distribution in relation to different water masses. Boletim do Instituto Oceanográfico $8,23-109$.

Vannucci M. (1963) On the ecology of Brazilian medusae at $25^{\circ}$ lat S. Boletim do Instituto Oceanográfico 13, 143-184.

Vannucci M., Santhakumari V. and dos Santos E.P. (1970) The ecology of hydromedusae from the Cochin area. Marine Biology 7, 49-58.

Van Ofwegen L.P. and Haddad M.A. (2011) A probably invasive new genus and new species of soft coral (Octocorallia: Alcyonacea: Clavulariidae) from Brazil. Zootaxa 3107, 38-46.

Vansteenbrugge L., Regenmortel T.V., Troch M., Vincx M. and Hostens K. (2015) Gelatinous zooplankton in the Belgian part of the North Sea and the adjacent Schelde estuary: spatio-temporal distribution patterns and population dynamics. Journal of Sea Research 97 , 28-39.

Van Walraven L., Langenberg V.T., Witte J.I.J. and Van der Veer H.W. (2015) Long-term patterns in 50 years of scyphomedusae catches in the western Dutch Wadden Sea in relation to climate change and eutrophication. Journal of Plankton Research 37, 151-167.

Yilmaz I.N. (2015) Collapse of zooplankton stocks during Liriope tetraphylla (Hydromedusa) blooms and dense mucilaginous aggregations in a thermohaline stratified basin. Marine Ecology 36, 595-610.

and

Zuo T., Wu Q., Wang J. and Li Z. (2016) Annual survey of the species diversity and assemblage dynamics of medusae in Laizhou Bay, Bohai Sea. Acta Ecologica Sinica 36, 5646-5656. (In Chinese with English abstract.)

\section{Correspondence should be addressed to:}

Lorena Silva Nascimento,

Zooplankton Laboratory,

Centro de Estudos do Mar,

Universidade Federal do Paraná,

Avenida Beira-mar, CP 61, ZIP code 83255- 976

Pontal do Sul, Pontal do Paraná,

Paraná, Brazil.

email: nascimento.s.lorena@gmail.com 